\title{
Preferential oxidation of CO on a La-Co-Ru perovskite-type oxide catalyst
}

\author{
Rosa Pereñíguez, ${ }^{1,2}$ Alfonso Caballero, ${ }^{1}$ and Davide Ferri ${ }^{2,3}$
}

${ }^{1}$ Instituto de Ciencia de Materiales de Sevilla (CSIC-Universidad de Sevilla) and Dpto. Química Inorgánica (Universidad de Sevilla), Av. Américo Vespucio, 49, E-41092 Sevilla, Spain

${ }^{2}$ Swiss Federal Laboratories for Materials Science and Technology, Empa, Ueberlandstrasse 129, CH-8600 Dübendorf, Switzerland

${ }^{3}$ Paul Scherrer Institut, CH-5232 Villigen PSI, Switzerland 


\begin{abstract}
A Ru-containing perovskite-type oxide $\mathrm{La}(\mathrm{Co}, \mathrm{Ru}) \mathrm{O}_{3}$ of nominal composition $\mathrm{LaCo}_{0.8} \mathrm{Ru}_{0.2} \mathrm{O}_{3}$ was prepared by ultrasonic spray combustion and tested for the preferential oxidation of $\mathrm{CO}$ (PROX). EXAFS indicated that Ru adopted the coordination environment of $\mathrm{Co}$ in $\mathrm{LaCoO}_{3}$ while $\mathrm{Co}$ was present as $\mathrm{LaCoO}_{3}$ and $\mathrm{Co}_{3} \mathrm{O}_{4}$. PROX activity was replaced by $\mathrm{CO}$ hydrogenation activity above $250{ }^{\circ} \mathrm{C}$. Short oxidation at $500{ }^{\circ} \mathrm{C}$ between temperature programmed reaction ramps did not restore the initial $\mathrm{La}(\mathrm{Co}, \mathrm{Ru}) \mathrm{O}_{3}$ structure but generated a catalyst with improved PROX activity compared to the initial $\mathrm{La}(\mathrm{Co}, \mathrm{Ru}) \mathrm{O}_{3}$. Under reductive PROX conditions the material experienced structural changes that improved its overall catalytic activity only if the catalyst was oxidized after each temperature programmed ramp.
\end{abstract}

Keywords: $\mathrm{Ru} ; \mathrm{LaCoO}_{3}$; $\mathrm{PROX}$; $\mathrm{CO}$ methanation; reduction; structural regeneration 


\section{Introduction}

Perovskite-type oxides $\left(\mathrm{ABO}_{3}\right)$ are acknowledged as efficient catalysts for oxidation reactions [1-5]. It was recognized early that when doped with transition and precious metals this class of mixed oxides exerts a stabilizing function towards the dopant to avoid formation of volatile oxides and catalyst degradation. To this end, ruthenium was the major focus of studies already in the early 70's as it became a potential candidate for the removal of $\mathrm{NO}_{\mathrm{x}}$ from treatment of exhaust gases of vehicles [6-8]. Moreover, the possibility to produce perovskite-type oxides with catalytically relevant B-site doping elements was shown to protect the metals from particle growth in automotive catalysis as a consequence of reversible segregation-incorporation within the perovskite-type structure [9]. Recently, the interest for Ru-doped perovskite-type oxides has been placed rather on high temperature applications such as fuel reforming [10-18] because of the thermal stability of perovskite-type oxides and the intrinsic activity of ruthenium. Fierro and co-workers [11-15] have shown that addition of $\mathrm{Ru}$ to $\mathrm{LaCoO}_{3}$ improves especially the stability of the catalyst to high temperature reaction conditions. Because of the reducing environment of these reactions, the reducible $\mathrm{LaCoO}_{3}$ can be used as an ideal catalyst precursor. During reaction or pretreatment, $\mathrm{La}_{2} \mathrm{O}_{3}$ or $\mathrm{La}_{2} \mathrm{O}_{2} \mathrm{CO}_{3}$ supported $\mathrm{Co}$ and $\mathrm{Ru}$ particles are generated and constitute the final catalyst. The improved catalytic activity of $\mathrm{Ru}$ was attributed to the enhanced reducibility of $\mathrm{LaCoO}_{3}$ by $\mathrm{Ru}$ and to the consequent improved formation of $\mathrm{Co}, \mathrm{Ru}$ and possible $\mathrm{Co}-\mathrm{Ru}$ metallic phases. This strategy could be exploited to generate suitable materials for catalytic processes operating at low and moderate temperatures. Therefore, in this work we use Ru-doped $\mathrm{LaCoO}_{3}$ prepared by ultrasonic spray combustion $[19,20]$ as a possible catalyst for preferential oxidation of $\mathrm{CO}$ in excess hydrogen (PROX) in a broad temperature range. $\mathrm{Ru}$ is an active metal for this reaction [21] but it also catalyzes $\mathrm{CO}$ hydrogenation to $\mathrm{CH}_{4}$ occurring at higher temperature than PROX [22]. Besides exploiting the reducibility of $\mathrm{LaCoO}_{3}$ 
enabling the segregation of $\mathrm{Ru}$, we show preliminary data on the structural regeneration of the catalyst, under sequential temperature programmed reaction and oxidation steps.

\section{Experimental}

An aqueous solution of $\mathrm{La}\left(\mathrm{NO}_{3}\right)_{3} \cdot 6 \mathrm{H}_{2} \mathrm{O}$ (Fluka, >99\%), $\mathrm{Co}\left(\mathrm{NO}_{3}\right)_{2} \cdot 6 \mathrm{H}_{2} \mathrm{O}$ (Sigma-Aldrich, $>98 \%$ ), $\mathrm{RuCl}_{3} \times \mathrm{xH}_{2} \mathrm{O}$ (Aldrich >99\%) and citric acid (Riedel-de Haën, >99.5\%) in the necessary molar ratio to obtain $\mathrm{LaCoO}_{3-\delta}$ and $\mathrm{LaCo}_{0.8} \mathrm{Ru}_{0.2} \mathrm{O}_{3-\delta}\left(\mathrm{La}(\mathrm{Co}, \mathrm{Ru}) \mathrm{O}_{3}\right)$ was atomized in a ultrasonic nebulizer and transported by air flow through a vertical quartz reactor heated to $600{ }^{\circ} \mathrm{C}$ [23]. The ratio between the amount of citric acid and the total amount of metal ions was 1 . The resulting oxide powders were collected on a heated membrane filter $\left(150{ }^{\circ} \mathrm{C}\right)$ and calcined at $600^{\circ} \mathrm{C}$ for $4 \mathrm{~h}$.

X-ray diffractograms (XRD) were recorded with a Philips X'pert Pro MPD diffractometer using Ni-filtered $\mathrm{Cu} \mathrm{K \alpha}$ radiation $(\lambda=1.5418 \AA$ ). In situ XRD data during temperature programmed reduction $\left(\mathrm{H}_{2}\right.$-TPR) were collected at steady state in $5 \mathrm{vol} \% \mathrm{H}_{2} / \mathrm{Ar}$ up to $700{ }^{\circ} \mathrm{C}$ $\left(10{ }^{\circ} \mathrm{C} / \mathrm{min}\right)$ and $70 \mathrm{vol} \% \mathrm{H}_{2} / \mathrm{N}_{2}$ up to $500^{\circ} \mathrm{C}\left(5^{\circ} \mathrm{C} / \mathrm{min}\right)$ at temperature increments of $25^{\circ} \mathrm{C}$ ( $2 \theta$ range, $24-56^{\circ}$; step size, $0.05^{\circ}$ ). The BET specific surface area was measured from $\mathrm{N}_{2}$ adsorption-desorption isotherms at $-196^{\circ} \mathrm{C}$ using a Micromeritics ASAP 2020 instrument. Temperature programmed reduction $\left(\mathrm{H}_{2}-\mathrm{TPR}\right)$ was performed in a setup equipped with a thermal conductivity detector (TCD) to quantify the $\mathrm{H}_{2}$ concentration and an online mass spectrometer (MS) to monitor products formation [24]. $\mathrm{CuO}$ was used for quantification of the $\mathrm{H}_{2}$ consumption. After heating in $5 \mathrm{vol} \% \mathrm{H}_{2} / \mathrm{Ar}$ to $700{ }^{\circ} \mathrm{C}\left(10^{\circ} \mathrm{C} / \mathrm{min}\right)$, cooling to room temperature and purging with $\mathrm{He}$, the sample was heated in 3 vol\% $\mathrm{O}_{2} / \mathrm{He}$ to $700{ }^{\circ} \mathrm{C}(10$ ${ }^{\circ} \mathrm{C} / \mathrm{min}$ ). This procedure was repeated three times and the reduction profiles were labelled as TPR-1, TPR-2 and TPR-3. Transmission extended X-ray absorption fine structure (EXAFS) 
spectra were collected at the Co $(7709 \mathrm{eV})$ and $\mathrm{Ru}(22117 \mathrm{eV}) \mathrm{K}$-edges (BM01B beamline, ESRF, Grenoble) using Co and Ru foils for energy calibration.

The preferential oxidation of CO (PROX) was carried out by heating the catalyst $(50 \mathrm{mg}$ ) in a quartz tubular reactor to $500{ }^{\circ} \mathrm{C}\left(1{ }^{\circ} \mathrm{C} / \mathrm{min}\right)$ in 1 vol\% $\mathrm{O}_{2}, 1$ vol\% $\mathrm{CO}$ and 70 vol\% $\mathrm{H}_{2}, 100$ $\mathrm{mL} / \mathrm{min}$ (He balance). After cooling to room temperature, the catalyst was heated to $500{ }^{\circ} \mathrm{C}$ in 20 vol\% $\mathrm{O}_{2} / \mathrm{He}$ followed by $5 \mathrm{~min}$ dwell at $500{ }^{\circ} \mathrm{C}$ and cooling to room temperature. Five activity-oxidation cycles were performed that were followed by five activity cycles without intermediate oxidation (Figure S1). The effluent gas was analyzed by gas chromatography (Varian GC-3800; TCD; Molecular Sieve $5 \AA$ and Porapak®-N columns). $\mathrm{CO}$ and $\mathrm{O}_{2}$ conversion, $\mathrm{CO}_{2}$ yield and $\mathrm{CH}_{4}$ yield were determined as follows:

$$
\begin{aligned}
& \mathrm{X}(\mathrm{CO})(\%)=100 \times\left(n \mathrm{CO}_{\text {in }}-n \mathrm{CO}_{\text {out }}\right) / n \mathrm{CO}_{\text {in }} \\
& \mathrm{X}\left(\mathrm{O}_{2}\right)(\%)=100 \times\left(n \mathrm{O}_{2 \text { in }}-n \mathrm{O}_{2 \text { out }}\right) / n \mathrm{O}_{2 \text { in }} \\
& \mathrm{Y}\left(\mathrm{CO}_{2}\right)(\%)=100 \times n \mathrm{CO}_{2 \text { out }} / n \mathrm{CO}_{\text {in }} \\
& \mathrm{Y}\left(\mathrm{CH}_{4}\right)(\%)=100 \times n \mathrm{CH}_{4 \text { out }} / n \mathrm{CO}_{\text {in }}
\end{aligned}
$$

where $n \mathrm{i}$ is the amount of every component (i) in moles.

\section{Results and Discussion}

The XRD pattern of $\mathrm{La}(\mathrm{Co}, \mathrm{Ru}) \mathrm{O}_{3}\left(30.2 \mathrm{~m}^{2} / \mathrm{g}\right)$ calcined at $600{ }^{\circ} \mathrm{C}$ exhibited only the reflections of the rhombohedral structure of $\mathrm{LaCoO}_{3}$ (ICDD, 01-084-0847, R-3c; Figure 1). The missing doublets characteristic of the rhombohedral structure reflected the low degree of criystallinity as a result of the low synthesis and calcination temperatures. The significant shift to lower $2 \theta$ values of the reflections compared to $\mathrm{LaCoO}_{3}$ suggests that $\mathrm{Ru}$ was inserted at the B-site [12]. The edge energy $(7723 \mathrm{eV})$ of the Co K-edge XANES spectrum of 
$\mathrm{La}(\mathrm{Co}, \mathrm{Ru}) \mathrm{O}_{3}$ (Figure 2) was intermediate between that of $\mathrm{LaCoO}_{3}\left(\mathrm{Co}^{3+}, 7724 \mathrm{eV}\right.$ ) and $\mathrm{Co}_{3} \mathrm{O}_{4}\left(\mathrm{Co}^{2+/ 3+}, 7717 \mathrm{eV}\right)$. The whiteline presented a second peak attributable to $\mathrm{Co}_{3} \mathrm{O}_{4}$. Beside the Co-O coordination shell at $1.5 \AA$, which did not match that of $\mathrm{Co}_{3} \mathrm{O}_{4}(1.7 \AA)$, the peak at ca. $3.2 \AA$ that is due to multiple contributions of Co-La, Co-Co, and Co-O-Co bonds was weaker than in $\mathrm{LaCoO}_{3}$ in the FT-EXAFS spectrum (Figure 2) suggesting a large degree of disorder induced by Co substitution [25]. The contribution at $2.5 \AA$ resembled the coordination environment of cobalt in $\mathrm{Co}_{3} \mathrm{O}_{4}$. These observations suggest the presence of a mixed local environment of $\mathrm{Co}$ and the coexistence of $\mathrm{LaCoO}_{3}$ and $\mathrm{Co}_{3} \mathrm{O}_{4}$ phases in $\mathrm{La}(\mathrm{Co}, \mathrm{Ru}) \mathrm{O}_{3}$. Its dispersion and amorphous character, reflecting the structural disorder observed in the FT-EXAFS of $\mathrm{La}(\mathrm{Co}, \mathrm{Ru}) \mathrm{O}_{3}$ explain the absence of $\mathrm{Co}_{3} \mathrm{O}_{4}$ in the XRD (Figure 1).

The Ru K-edge XANES spectrum of $\mathrm{La}(\mathrm{Co}, \mathrm{Ru}) \mathrm{O}_{3}$ (Figure 2) did not match the spectra of reference materials with nominal $\mathrm{Ru}$ oxidation state $+3\left(\mathrm{RuCl}_{3}\right)$ and $+4\left(\mathrm{RuO}_{2}\right)$. It was composed of two major peaks due to $1 \mathrm{~s} \rightarrow 5 \mathrm{p}_{\mathrm{x}}$ and $1 \mathrm{~s} \rightarrow 5 \mathrm{p}_{\mathrm{y}(\mathrm{z})}$ transitions in distorted $\mathrm{RuO}_{6}$ octahedra in perovskites [26], implying that Ru adopted the oxidation and coordination states of the B-site. By comparison of the position of the maximum of the first derivative of $\mathrm{La}(\mathrm{Co}, \mathrm{Ru}) \mathrm{O}_{3}$ with that of compounds with oxidation state $+3\left(\mathrm{RuCl}_{3}\right),+4\left(\mathrm{RuO}_{2}\right),+4.5$ $\left(\mathrm{Pb}_{2} \mathrm{Ru}_{2} \mathrm{O}_{6.5}\right)$ and $+5\left(\mathrm{Ca}_{2} \mathrm{YRuO}_{6}\right)($ Figure 2)[27], we assign $\mathrm{Ru}$ an oxidation state close to +5 and octahedral coordination. This oxidation state could be justified by the similar ionic radius of $\mathrm{Ru}^{5+}(0.705 \AA)$ in octahedral coordination and $\mathrm{Co}^{3+}(0.685 \AA)$ compared to lower oxidation states of $\mathrm{Ru}\left(\mathrm{Ru}^{4+}: 0.76 \AA\right.$ or $\left.\mathrm{Ru}^{3+}: 0.82 \AA\right)$ [28]. The slightly larger radius of $\mathrm{Ru}^{5+}$ induces the shift to lower diffraction angles in the XRD. Because no Ru K-edge spectrum was reported, we could not compare our spectra with those measured by Mota et al. [13], who proposed $\mathrm{Ru}^{+4}$ in $\mathrm{LaCo}_{0.8} \mathrm{Ru}_{0.2} \mathrm{O}_{3}$. The high oxidation state of $\mathrm{Ru}$ is consistent with the large degree of disorder evident from the FT spectrum of the Co K-edge and the partial reduction 
of $\mathrm{Co}^{3+}$ to $\mathrm{Co}^{2+}$ related to the presence of $\mathrm{Co}_{3} \mathrm{O}_{4}$. Charge compensation/redistribution and the unit cell distortion can suggest the Co segregation if all Ru adopted the coordination state of Co and was all integrated in the perovskite lattice. Assuming that Co was present only in oxidation state +3 in the perovskite phase, while $\mathrm{Ru}$ was in the oxidation state +5 and all exchanged in the perovskite phase, the stoichiometry of the B-site should be $\mathrm{Co}^{3+}{ }_{0.67} \mathrm{Ru}^{5+}{ }_{0.2}$ (overall oxidation state of $\mathrm{B}$-site, +3 ) rather than the theoretical $\mathrm{Co}^{3+}{ }_{0.8} \mathrm{Ru}^{5+}{ }_{0.2}(+3.4)$. The difference of Co concentration in the perovskite is thus compensated by the formation of $\mathrm{Co}_{3} \mathrm{O}_{4}$.

The $\mathrm{H}_{2}$-TPR profile of $\mathrm{La}(\mathrm{Co}, \mathrm{Ru}) \mathrm{O}_{3}$ exhibited three major peaks (TPR-1, Figure 3) and $\mathrm{Ru}$ improved the reducibility of $\mathrm{LaCoO}_{3}$ in agreement with previous observations [12]. According to the $\mathrm{H}_{2}$ consumption values and after deconvolution of the different contributions of TPR-1 (Table S1), we assume that the reduction of the cobalt phase took place in two steps, i.e. $\mathrm{Co}^{2.95+} \rightarrow \mathrm{Co}^{2+}\left(375^{\circ} \mathrm{C}\right)$ and $\mathrm{Co}^{2+} \rightarrow \mathrm{Co}^{0}\left(>500{ }^{\circ} \mathrm{C}\right)$. The first peak at $295{ }^{\circ} \mathrm{C}$ is ascribed to the reduction of ruthenium. The values of theoretical $\left(\Delta \mathrm{n}_{\mathrm{T}}{ }^{+}=1\right)$ and experimental $\left(\Delta \mathrm{n}_{\mathrm{E}}{ }^{+}=0.81\right)$ extent of electron exchange for this step suggest that reduction of ruthenium may have been partial and could have been completed together with the subsequent step, the reduction of cobalt $\left(375^{\circ} \mathrm{C}\right)$. For the peak at $375^{\circ} \mathrm{C}$ we measured an excess of $\mathrm{H}_{2}$ consumption $\left(\Delta \mathrm{n}_{\mathrm{E}}{ }^{+}=1.13\right.$ against $\left.\Delta \mathrm{n}_{\mathrm{T}}{ }^{+}=0.76\right)$. Segregated $\mathrm{Ru}^{0}$ promoted likely the first reduction peak of cobalt $\left(250-450{ }^{\circ} \mathrm{C}\right)$ by hydrogen spillover. The second (TPR-2) and third (TPR-3) $\mathrm{H}_{2}$-TPR profiles were different compared to TPR-1. The two $\mathrm{H}_{2}$ consumption peaks below $400{ }^{\circ} \mathrm{C}$ of TPR-1 merged in a sharp peak centered at ca. $350{ }^{\circ} \mathrm{C}$. Similarly, the clear event at $550{ }^{\circ} \mathrm{C}$ became a shoulder of the peak at $605^{\circ} \mathrm{C}$, which shifted to ca. $590{ }^{\circ} \mathrm{C}$. It is evident that TPR-2 and TPR-3 are very similar suggesting the structural reversibility of the material over redox cycles after the first reduction segment. Therefore, the 
short oxidation at $700{ }^{\circ} \mathrm{C}$ did not restore completely the initial structure obtained after synthesis and calcination at $600{ }^{\circ} \mathrm{C}$.

In order to explain these differences, in situ XRD was carried out during $\mathrm{H}_{2}$-TPR in 5 vol\% $\mathrm{H}_{2}$ (Figure 4). Ideally the structural changes should coincide with the reduction events observed in Figure 3. At ca. $400{ }^{\circ} \mathrm{C}$ the rhombohedral $\mathrm{LaCoO}_{3}$ structure vanished in favor of the oxygen deficient $\mathrm{La}_{2} \mathrm{Co}_{2} \mathrm{O}_{5} . \mathrm{La}_{2} \mathrm{O}_{3}$ appeared already at $500{ }^{\circ} \mathrm{C}$; at $700{ }^{\circ} \mathrm{C}$ there was no remaining reflection of a perovskite-type oxide. However, no $\mathrm{Ru}$-phase and $\mathrm{Co}^{0}$ were detected indicating that $\mathrm{Ru}$ and $\mathrm{Co}$ were well dispersed on $\mathrm{La}_{2} \mathrm{O}_{3}$. Therefore, the results confirm that the first $\mathrm{H}_{2}$-TPR peak corresponds to the reduction of $\mathrm{Ru}^{5+}$ and of $\mathrm{Co}^{3+}$ $\left(\mathrm{Ru} / \mathrm{LaCoO}_{3}\right)$ to $\mathrm{Co}^{2+}\left(\mathrm{Ru} / \mathrm{La}_{2} \mathrm{Co}_{2} \mathrm{O}_{5}\right)$, while the peak at higher temperature belongs to the complete reduction of cobalt and loss of the perovskite phase. Figure S2a and Figure S2b show the diffractograms of calcined $\mathrm{La}(\mathrm{Co}, \mathrm{Ru}) \mathrm{O}_{3}$ and of the sample after one in situ XRD redox cycle, respectively. The diminished intensity of the reflections indicated that the short oxidation at $700{ }^{\circ} \mathrm{C}$ and the subsequent cooling in the same environment generated a more disordered perovskite structure. However, without any other experimental evidence, we speculate that the same $2 \theta$ position of the diffraction peaks suggests that $\mathrm{Ru}$ reverted in the perovskite structure.

$\mathrm{La}(\mathrm{Co}, \mathrm{Ru}) \mathrm{O}_{3}$ was subjected to a sequence of consecutive temperature programmed ramps in the preferential $\mathrm{CO}$ oxidation (PROX) feed alternated to temperature programmed oxidation ramps (Figure S1). Under similar reducing conditions of PROX, an in situ XRD measurement with 70 vol\% $\mathrm{H}_{2}$ (Figure S3) demonstrated the same phase transitions observed with 5 vol\% $\mathrm{H}_{2}$ but at lower temperature: $\mathrm{La}_{2} \mathrm{Co}_{2} \mathrm{O}_{5}$ was observed at $200{ }^{\circ} \mathrm{C}$ and reduction to $\mathrm{La}_{2} \mathrm{O}_{3}$ occurred at ca. $500^{\circ} \mathrm{C}$.

Figure 5 shows the CO conversion data for the preferential CO oxidation (PROX), while Figure S4 displays the $\mathrm{O}_{2}$ conversion and $\mathrm{CO}_{2}$ yield data. In the first PROX profile (R1) the 
reaction was initiated above $200{ }^{\circ} \mathrm{C}$ and $90 \% \mathrm{CO}$ conversion was attained at $350{ }^{\circ} \mathrm{C}$. The relatively broad temperature window in which activity was measured allowed capturing a change of reaction regime from the preferential $\mathrm{CO}$ oxidation to $\mathrm{CO}$ methanation above 300 ${ }^{\circ} \mathrm{C}[29]$. The activity profiles obtained after the first oxidation including heating and cooling segments to $500{ }^{\circ} \mathrm{C}$ (R2-R5) demonstrated that the temperature regime for PROX shifted to lower temperature by ca. $100{ }^{\circ} \mathrm{C}$ (CO conversion, Figure 5; $\mathrm{O}_{2}$ conversion, Figure S4). Full $\mathrm{CO}$ conversion was reached at $300{ }^{\circ} \mathrm{C}$ just before activity loss. The kink in the $\mathrm{CO}$ conversion at $200{ }^{\circ} \mathrm{C}$ corresponded to the maximum $\mathrm{CO}_{2}$ yield. Comparison of Figure 5 and Figure $\mathbf{S 4}$ suggests that between 50 and $200^{\circ} \mathrm{C}$ PROX dominated over $\mathrm{H}_{2}$ combustion though the stoichiometry of the reactions indicates that the latter was occurring parallel to PROX to some extent. $\mathrm{CO}$ methanation replaced $\mathrm{CO}$ oxidation above $250{ }^{\circ} \mathrm{C}$ after the first activity run (Figure S4). The loss of activity above $350{ }^{\circ} \mathrm{C}$ mirrored the decrease of $\mathrm{CH}_{4}$ yield. The activity profiles remained substantially unchanged after R2 confirming that the structural changes did not proceed further. This observation is in agreement with the $\mathrm{H}_{2}$-TPR data of Figure 4 showing that consecutive TPR profiles after the first and reoxidation $\left(700{ }^{\circ} \mathrm{C}\right)$ were very similar.

In absence of further in situ characterization data, the observed activation can be explained as follows. The reduction of the perovskite-type structure during the temperature programmed reaction under reducing conditions $\left(70\right.$ vol\% $\left.\mathrm{H}_{2}\right)$ to $500{ }^{\circ} \mathrm{C}$ caused the reduction and segregation of $\mathrm{Ru}^{0}$ and the formation of a $\mathrm{Ru}^{0}-\mathrm{Co}^{0} / \mathrm{La}_{2} \mathrm{O}_{3}$ catalyst. We cannot conclude whether a Ru-Co alloy was formed. After oxidation at $500{ }^{\circ} \mathrm{C}$, that is milder than the temperatures of synthesis and initial calcination, part of the material was restored into A- and B-site deficient $\mathrm{LaCoO}_{3}$ and this was likely not sufficient to revert completely to the initial oxidation and coordination environment, however this treatment results in a better catalyst. The subsequent $\mathrm{H}_{2}$-TPR experiments (Figure 4) then could correspond predominantly to 
reduction of oxidized $\mathrm{Ru}$ and $\mathrm{LaCoO}_{3}$ together with the incorporated $\mathrm{Ru}\left(\mathrm{La}(\mathrm{Co}, \mathrm{Ru}) \mathrm{O}_{3}\right)$ and $\mathrm{Co}_{3} \mathrm{O}_{4}$. In the case of the catalytic activity, the consecutive temperature programmed ramps after the first oxidation involved most likely $y \mathrm{RuO}_{2} / \mathrm{La}_{\mathrm{y}} \mathrm{Co}_{1-\mathrm{x}} \mathrm{Ru}_{\mathrm{x}-\mathrm{y}} \mathrm{O}_{3} /(1-\mathrm{y}) \mathrm{La}_{2} \mathrm{O}_{3}$ rather than $\mathrm{La}(\mathrm{Co}, \mathrm{Ru}) \mathrm{O}_{3}$ that reduced upon heating under reducing conditions generating $\mathrm{Ru}^{0}$ particles. We cannot exclude that also a fraction of $\mathrm{Co}^{0}$ obtained at the end of the reaction run at $500{ }^{\circ} \mathrm{C}$ could have been oxidized to $\mathrm{Co}_{3} \mathrm{O}_{4}$ rather than $\mathrm{LaCoO}_{3}$ and that therefore the activity is influenced by both $\mathrm{Ru}^{0}$ and $\mathrm{Co}^{0}$ species. The segregated metal phase is responsible for the CO hydrogenation activity above $250^{\circ} \mathrm{C}$.

When no intermediate oxidation was carried out, catalytic activity declined (Figure 5). After the shift to lower temperature in R6, maximum CO conversion (70\%) was measured at 290 ${ }^{\circ} \mathrm{C}$ and was accompanied by an increase in reaction temperature. $\mathrm{CH}_{4}$ was the major product. Without spectroscopic results on the sample after each activity run, we can only speculate that $\mathrm{Ru}^{0}-\mathrm{Co}^{0} / \mathrm{La}_{2} \mathrm{O}_{3}$ obtained under reducing conditions at the end of the activity run was subject to metal particle growth. The presence of reduced metals under these conditions is responsible for the selective $\mathrm{CO}$ hydrogenation.

We infer, from the characterization and activity data, that without pretreatment the structure of $\mathrm{La}(\mathrm{Co}, \mathrm{Ru}) \mathrm{O}_{3}$ changes during reaction due to the reducing conditions, generating an active material for $\mathrm{CO}$ hydrogenation. Hence, $\mathrm{La}(\mathrm{Co}, \mathrm{Ru}) \mathrm{O}_{3}$ can be used as catalyst precursor for PROX (oxidized catalyst) and CO methanation (reduced catalyst). Strategies are available to regenerate the initial material for example to avoid metal particle growth or even poisoning. Short mid temperature oxidation $\left(500{ }^{\circ} \mathrm{C}\right.$, after PROX) is able to regenerate only partly the initial structure, but this is sufficient to generate a more active catalyst for PROX. On the contrary, continuous reducing conditions are less favourable for the generation of an active catalyst for PROX and CO hydrogenation is promoted. 


\section{Acknowledgments}

The authors kindly acknowledge the financial support from the Spanish Ministry of Research (Project CTQ2014-60524-R), the University of Seville for a scholarship for R.P. and the Swiss National Science Foundation (SNF). The European Synchrotron Research Facility (ESRF) is acknowledged for beamtime allocation at the Swiss-Norwegian beamline (SNBL).

The assistance of Dr. A. Kambolis and A. Rodriguez-Gomez during beamtime is highly appreciated.

\section{References}

[1] G. Parravano, J. Am. Chem. Soc., 75 (1953) 1497.

[2] D.W. Johnson, P.K. Gallagher, Thermochimica Acta, 7 (1973) 303.

[3] R.J.H. Voorhoeve, J.P. Remeika, P.E. Freeland, B.T. Matthias, Science, 177 (1972) 353.

[4] S. Royer, D. Duprez, ChemCatChem, 3 (2011) 24.

[5] N. Yamazoe, Y. Teraoka, Catal. Today, 8 (1990) 175.

[6] M. Skoglundh, L. Lowendahl, K. Jansson, L. Dahl, M. Nygren, Appl. Catal. B:Environmental, 3 (1994) 259.

[7] L.E. Trimble, Mater. Res. Bull., 9 (1974) 1405.

[8] R.J.H. Voorhoeve, J.P. Remeika, L.E. Trimble, Mater. Res. Bull., 9 (1974) 1393.

[9] Y. Nishihata, J. Mizuki, T. Akao, H. Tanaka, M.-. Uenishi, M. Kimura, T. Okamoto, N. Hamada, Nature, 418 (2002) 164.

[10] D.J. Liu, M. Krumpelt, Int. J. Appl. Technol., 2 (2005) 301.

[11] N. Mota, M.C. Alvarez-Galvan, S.M. Al-Zahrani, R.M. Navarro, J.L.G. Fierro, Int. H. Hydr. En., 37 (2012) 7056. 
[12] N. Mota, M.C. Alvarez-Galván, R.M. Navarro, S.M. Al-Zahrani, A. Goguet, H. Daly, W. Zhang, A. Trunschke, R. Schlögl, J.L.G. Fierro, Appl. Catal. B:Environmental, 113-114 (2012) 271-280.

[13] N. Mota, L. Barrio, C. Alvarez-Galvan, F. Fauth, R.M. Navarro, J.L.G. Fierro, J. Phys. Chem. C, 119 (2015) 16708-16723.

[14] N. Mota, R.M. Navarro, M.C. Alvarez-Galvan, S.M. Al-Zahrani, J.L.G. Fierro, J. Power Sources, 196 (2011) 9087-9095.

[15] R.M. Navarro, M.C. Alvarez-Galvan, J.A. Villoria, I.D. Gonzalez-Jimenez, F. Rosa, J.L.G. Fierro, Appl. Catal. B:Environmental, 73 (2007) 247.

[16] H.R. Gurav, R. Bobade, V.L. Das, S. Chilukuri, Ind. J. Chem., 51A (2012) 1339.

[17] E. Pietri, A. Barrios, O. Gonzalez, M.R. Goldwasser, M.J. Perez-Zurita, M.L. Cubeiro, J. Goldwasser, L. Leclercq, G. Leclercq, L. Gingembre, Stud. Surf. Sci. Catal., 136 (2001) 381. [18] M.R. Goldwasser, M.E. Rivas, E. Pietri, M.J. Perez-Zurita, M.L. Cubeiro, L. Gingembre, L. Leclercq, G. Leclercq, Appl. Catal. A:General, 255 (2003) 45.

[19] R. Pereniguez, V.M. Gonzalez-delaCruz, A. Caballero, J.P. Holgado, Appl. Catal. B:Environmental, 123 (2012) 324-332.

[20] D. Ferri, A. Heel, D. Burnat, Aerosol spray synthesis of perovskite-type oxides, in Perovskites and related mixed oxides: concepts and applications, P. Granger, V.I. Parvulescu, S. Kaliaguine, W. Prellier (Eds.), Wiley-VCH Verlag GmbH \& Co. KGaA, 2016, pp. 69.

[21] S.H. Oh, R.M. Sinkevitch, J. Catal., 142 (1993) 254.

[22] E.D. Park, D. Lee, H.C. Lee, Catal. Today, 139 (2009) 280.

[23] X. Wei, P. Hug, R. Figi, M. Trottmann, A. Weidenkaff, D. Ferri, Appl. Catal. B:Environmental, 94 (2010) 27-37.

[24] P. Malet, A. Caballero, J. Chem. Soc., Faraday Trans. I, 84 (1988) 2369-2375. 
[25] J.L. Hueso, J.P. Holgado, R. Pereniguez, S. Mun, M. Salmeron, A. Caballero, J. Solid State Chem., 183 (2010) 27-32.

[26] M. Mizumaki, K. Yoshii, Y. Hinatsu, Y. Doi, T. Uruga, Phys. Scripta, T115 (2005) 513.

[27] T. Vitova, S. Mangold, C. Paulmann, M. Gospodinov, V. Marinova, B. Mihailova, Phys. Rev. B, 89 (2014).

[28] R.D. Shannon, Acta Crystallogr. Sect. A, 32 (1976) 751-767.

[29] X. Chen, J.J. Delgado, J.M. Garcia, S. Zerrad, J.M. Cies, S. Bernal, J. Catal., 299 (2013) 272-283. 


\section{Figure captions}

Figure 1. X-ray diffraction patterns of $\mathrm{LaCoO}_{3}$ and $\mathrm{La}(\mathrm{Co}, \mathrm{Ru}) \mathrm{O}_{3}$. The right panel details the major reflection line.

Figure 2. Co K-edge XANES, non-phase shift corrected FT-EXAFS spectra of $\mathrm{LaCoO}_{3}$ and $\mathrm{La}(\mathrm{Co}, \mathrm{Ru}) \mathrm{O}_{3}$, Ru K-edge XANES spectra of $\mathrm{La}(\mathrm{Co}, \mathrm{Ru}) \mathrm{O}_{3}$ and reference compounds, and first derivative of the $\mathrm{Ru}$ K-edge XANES spectra of $\mathrm{La}(\mathrm{Co}, \mathrm{Ru}) \mathrm{O}_{3}$ and reference compounds.

Figure 3. Temperature-programmed reduction profiles of $\mathrm{La}(\mathrm{Co}, \mathrm{Ru}) \mathrm{O}_{3}$. The bottom profile belongs to $\mathrm{LaCoO}_{3}$.

Figure 4. In situ XRD patterns of $\mathrm{La}(\mathrm{Co}, \mathrm{Ru}) \mathrm{O}_{3}$ recorded during $\mathrm{H}_{2}$-TPR with 5 vol\% $\mathrm{H}_{2}$. Symbols: $(\nabla)$ hexagonal $\mathrm{La}_{2} \mathrm{O}_{3}$; (O) distorted rhombohedral $\mathrm{LaCoO}_{3}$, (*) brownmillerite $\mathrm{La}_{2} \mathrm{Co}_{2} \mathrm{O}_{5}$.

Figure 5. $\mathrm{CO}$ conversion in consecutive PROX activity measurements of $\mathrm{La}(\mathrm{Co}, \mathrm{Ru}) \mathrm{O}_{3}$ (a) with and (b) without intermediate oxidation at $500{ }^{\circ} \mathrm{C}$. Profiles marked with $*$ are the ones shown in (a). 


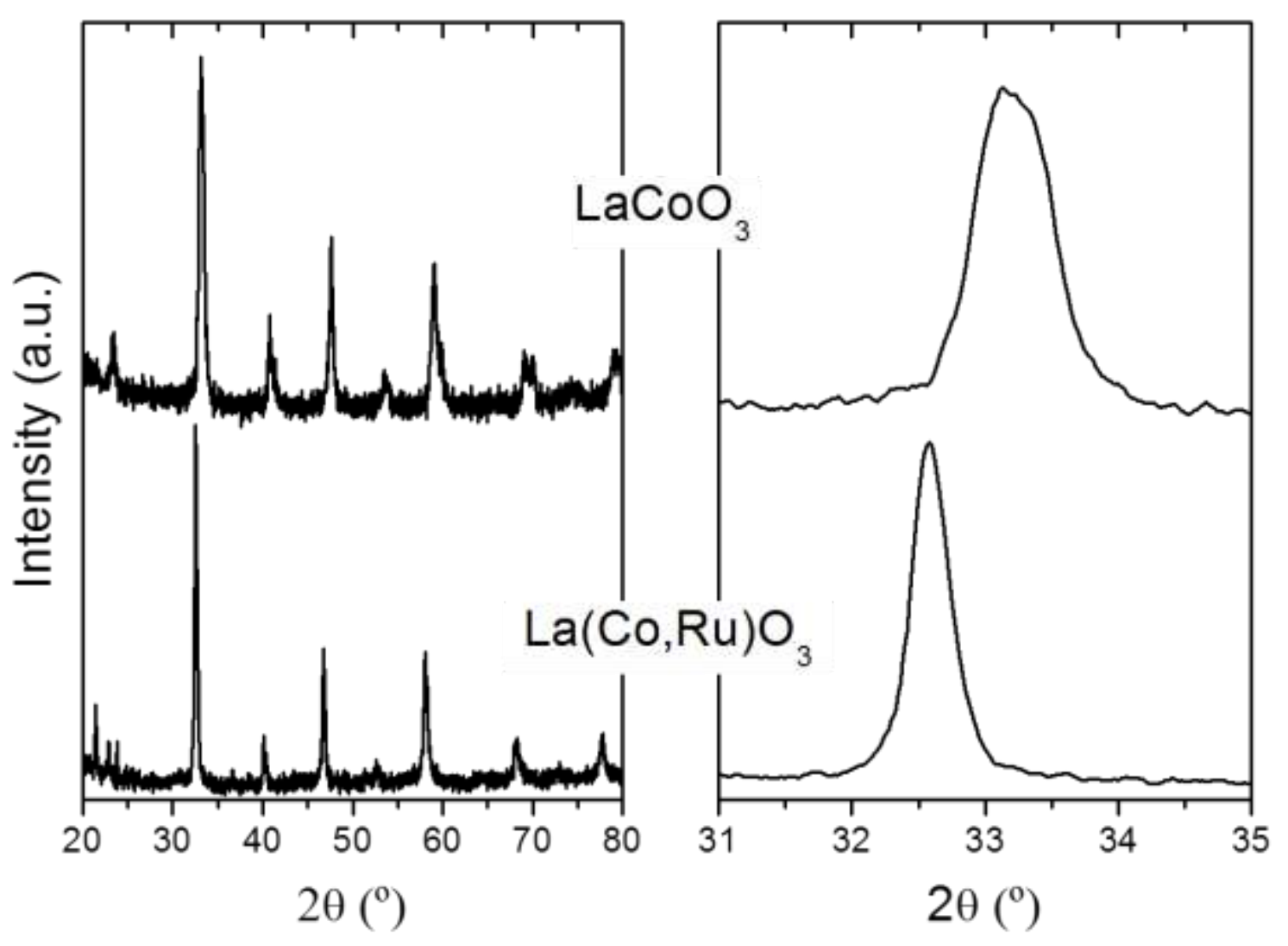

Figure 1 

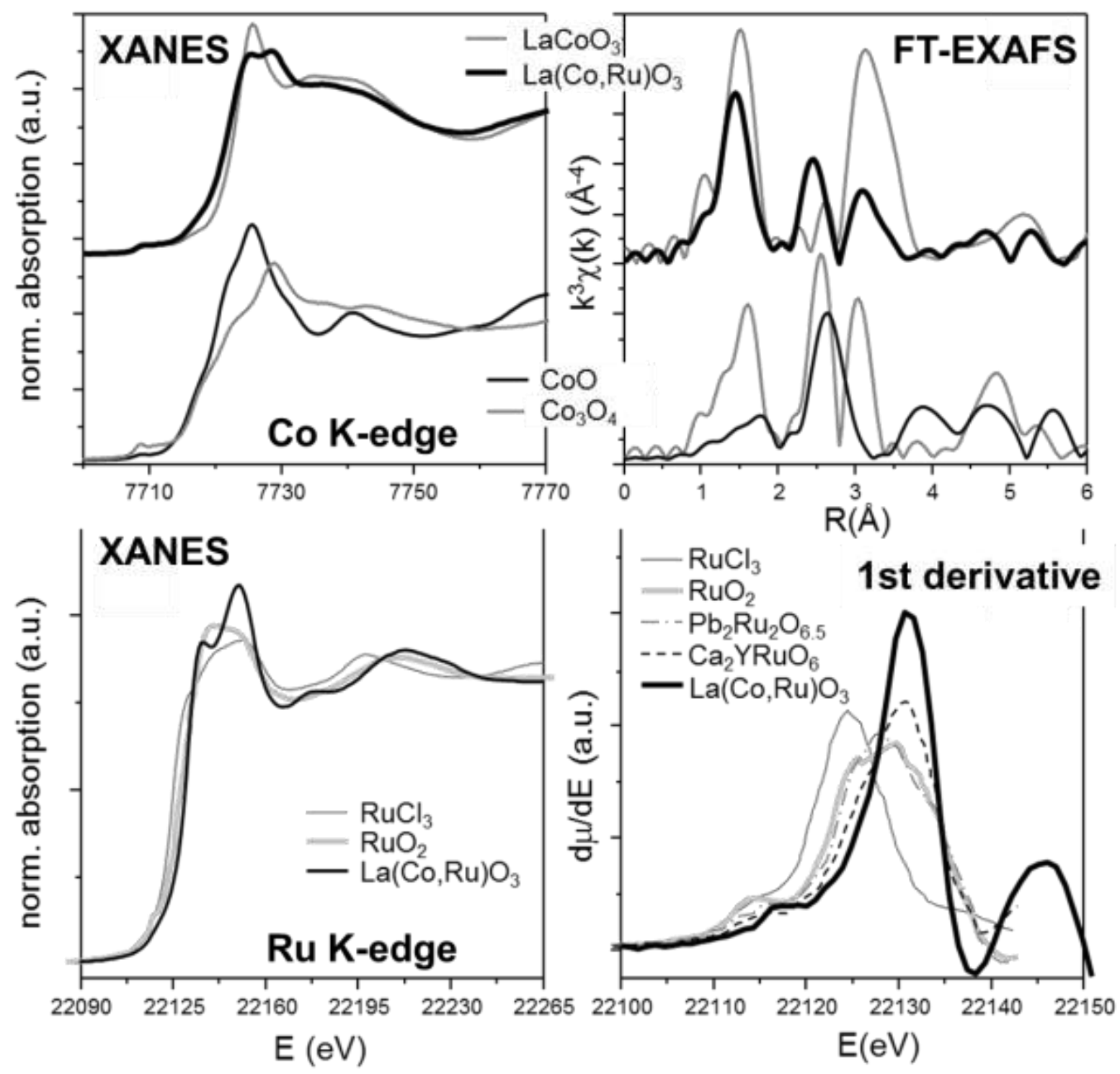

Figure 2 


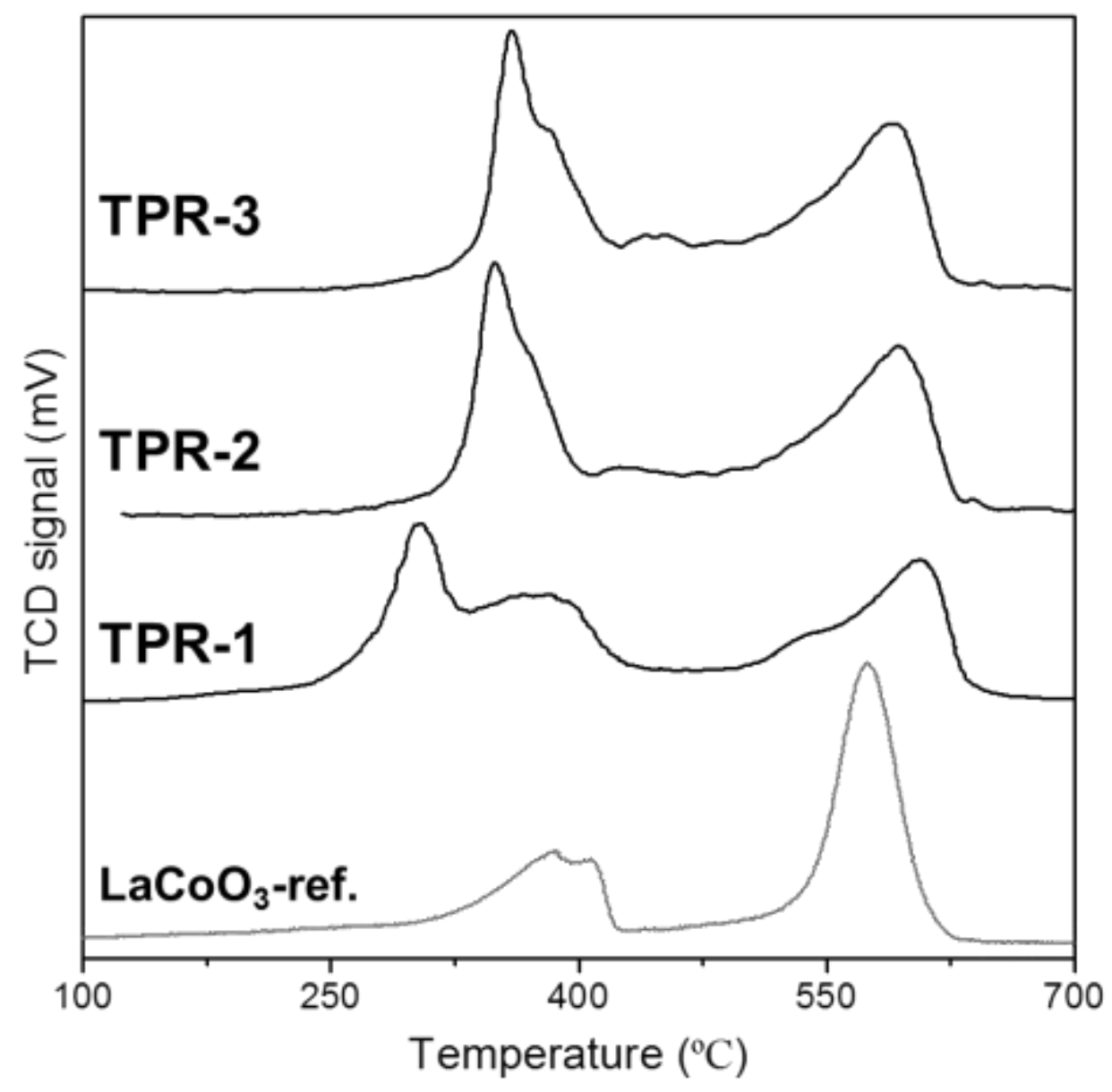

Figure 3 


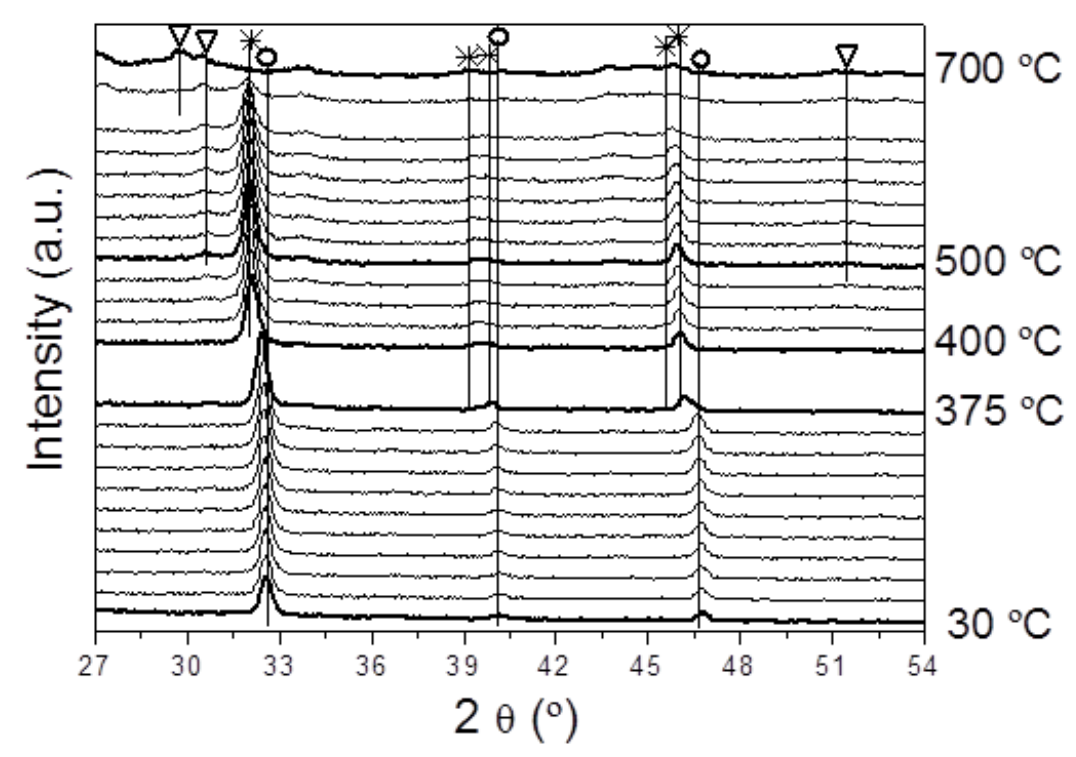

Figure 4 


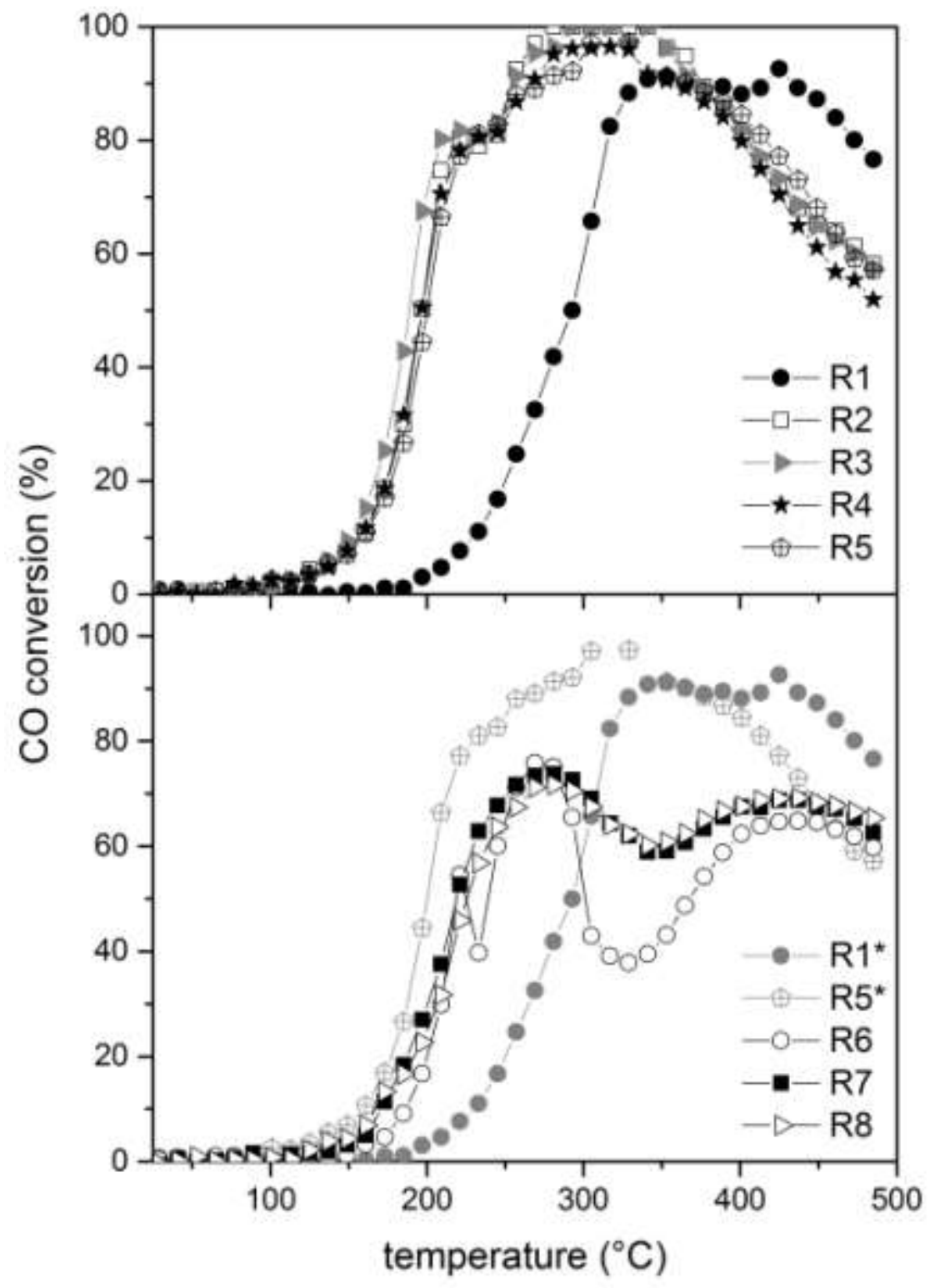

Figure 5 
Graphical abstract

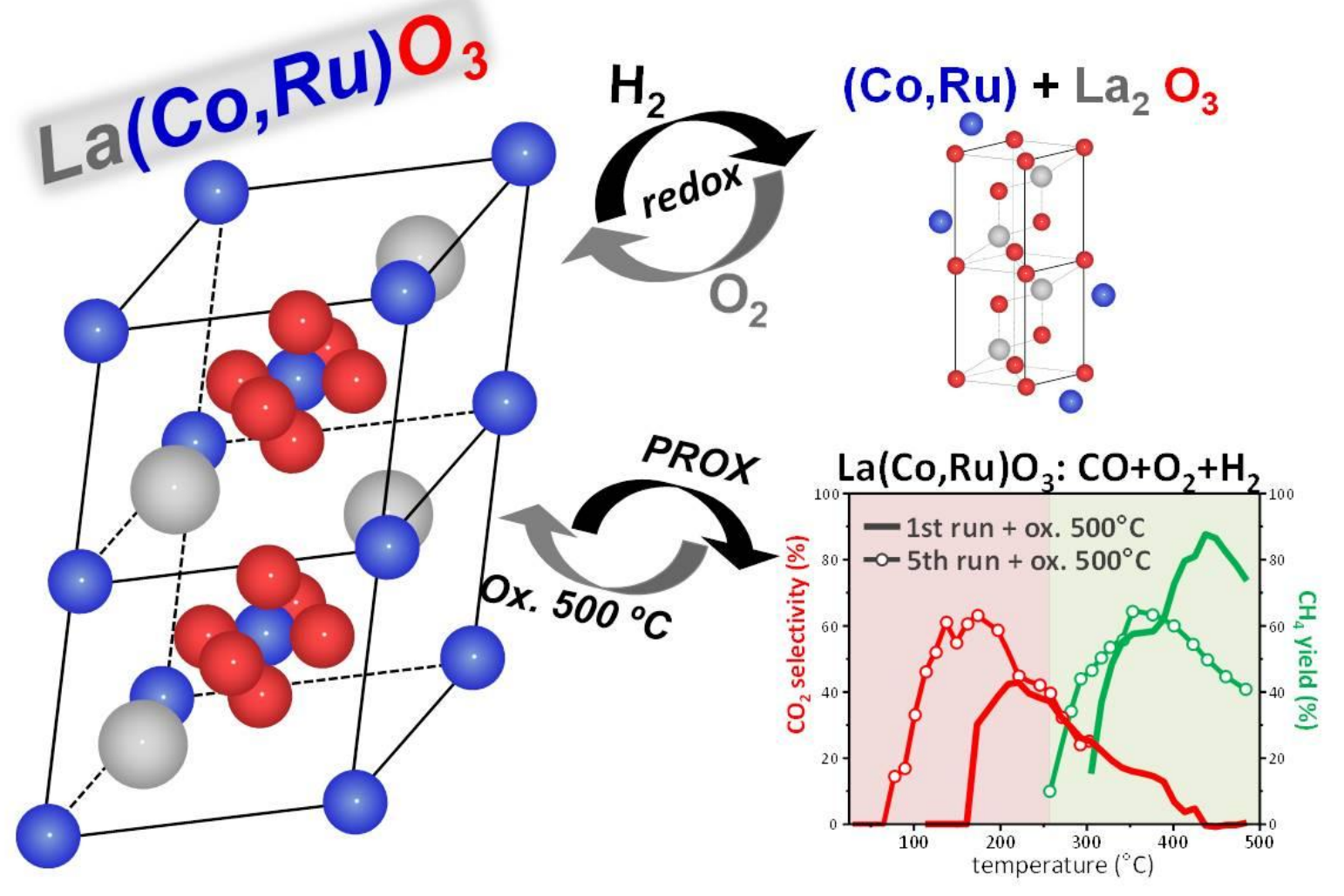

